\title{
Domino structures evolution in strike-slip shear zones; the importance of the cataclastic flow
}

\author{
N. Moreira ${ }^{\mathrm{a}, \mathrm{b}, *}$, R. Dias ${ }^{\mathrm{a}, \mathrm{b}, \mathrm{c}, *}$ \\ ${ }^{a}$ Research Laboratory of Industrial and Ornamental Rocks (LIRIO-ECTUE), Pole of Estremoz, University of Évora, Convento das Maltezas, 7100-513, Estremoz, Portugal \\ ${ }^{\mathrm{b}}$ Earth Sciences Institute (ICT), Pole of the University of Évora, Rua Romão Ramalho, $n^{\circ}$ 59, 7000-671, Évora, Portugal \\ ${ }^{c}$ Department of Geosciences, Sciences and Technology School, University of Évora, Portugal
}

\section{A R T I C L E I N F O}

\section{Keywords:}

Domino structures

Brittle-ductile deformation

Heterogeneous simple shear

Cataclastic flow

Iberian Variscides

\begin{abstract}
A B S T R A C T
The Porto-Tomar-Ferreira do Alentejo dextral Shear Zone is one of the most important structures of the Iberian Variscides. In its vicinity, close to Abrantes (Central Portugal), a localized heterogeneous strain pattern developed in a decimetric metamorphic siliceous multilayer. This complex pattern was induced by the $\mathrm{D}_{2}$ dextral shearing of the early $S_{0} / / S_{1}$ foliation in brittle-ductile conditions, giving rise to three main shear zone families. One of these families, with antithetic kinematics, delimits blocks with rigid clockwise rotation surrounded by coeval cataclasites, generating a local domino structure.

The proposed geometrical and kinematic analysis, coupled with statistical studies, highlights the relation between subsidiary shear zones and the main shear zone. Despite the heterogeneous strain pattern, a quantitative approach of finite strain was applied based on the restoration of the initial fracture pattern. This approach shows the importance of the cataclastic flow coupled with the translational displacement of the domino domain in solving space problems related to the rigid block rotation. Such processes are key in allowing the rigid block rotation inside shear zones whenever the simple shear component is a fundamental mechanism.
\end{abstract}

\section{Introduction}

The kinematics of shear zones is not an easy subject due to the complexities arising during heterogeneous internal deformation (e.g. Passchier and Trouw, 2005 and references herein). Dominos (sometimes called bookshelf structures) are one of the common strain accommodation structures developed in shear zones. They have been described from low to high-grade metamorphic rocks, although they are commonly developed in brittle to ductile-brittle deformation regimes (Mandl, 2000; Ribeiro, 2002; Goscombe and Passchier, 2003; Figueiredo et al., 2004), obeying the Coulomb criterion for failure (Jaeger and Cook, 1979).

These structures are usually characterized by the rotation of blocks, often bounded by one dominant shear/fracture orientation (Mandl, 2000; Nixon et al., 2011; Fossen, 2010). However, in some very specific situations, dominos can be developed without block rotation, because each block could slide past each other during bulk shearing (Samanta et al., 2002). Thus, dominos are often used as a shear sense criteria (Passchier et al., 1990; Mandl, 2000; Goscombe and Passchier, 2003; Goscombe et al., 2004; Passchier and Trouw, 2005; Fossen, 2010), helping to understand the kinematics of shear zones. The careful analysis of their geometry, kinematics and genetic mechanism becomes essential to a correct dynamic interpretation of shear zones.

Dominos and domino-like structures can either have antithetic or synthetic rotation relative to the main shear (Fig. 1A; Goscombe and Passchier, 2003; Dabrowski and Grasemann, 2014), which is a major constrain for their use as kinematic criteria. This is not a major problem in extensional regimes, where rotation of dominos generally occurs antithetically to the main low angle ductile décollement (Wernicke and Burchfiel, 1982; Mandl, 1987; Axen, 1988; Fossen and Hesthammer, 1998; Bahroudi et al., 2003; Karlstrom et al., 2010). Nevertheless, as in strike-slip environments both types of block rotations are common, their use as a kinematic criteria is more problematic (Cowan et al., 1986; Mandl, 2000; La Femina et al., 2002; Goscombe and Passchier, 2003; Goscombe et al., 2004; Nixon et al., 2011; Dabrowski and Grasemann, 2014; Dias et al., 2017). In such regimes, the synthetic or the antithetic block rotation seems to be controlled by factors as flow type, rheological contrast, initial angle of the previous foliation to the main shear zone, existence of previous anisotropies bounding blocks or the shape of the block (Mandal et al., 2000; Goscombe and Passchier, 2003; Dabrowski and Grasemann, 2014). However, analogue experiments indicate that the orientation and the spacing of fractures in the

\footnotetext{
* Corresponding authors. Research Laboratory of Industrial and Ornamental Rocks (LIRIO-ECTUE), Pole of Estremoz, University of Évora, Convento das Maltezas, 7100-513, Estremoz, Portugal.

E-mail addresses: nmoreira@estremoz.cienciaviva.pt (N. Moreira), rdias@uevora.pt (R. Dias).
} 
be accommodated with such mechanism. In any model trying to explain the genesis of dominos, such inconsistency must be explained.

The issues stressed above are no resolvable invoking homogeneous deformation, unless the shear zones are operated in a transpressive regime, or if a local volume variation exists at the interfaces of the blocks.

The geometrical and kinematical studies in the Abrantes domino highlights the importance of cataclastic flow within brittle-ductile shear zones. The cataclastic material behaves as a plastic matrix, removing material from the overlap domains into the gap zones. In cases where $\beta_{0}$ is greater than $90^{\circ}$, gaps prevail between blocks (Fig. 1C), facilitating their rigid rotation.

The presence of subsidiary antithetic shear zones (SF1), together with the main boundary shear zones (MSZ), generates an internal clockwise flow, responsible for the rigid block spinning. Such process, coupled with the cataclastic flow, led to important translational mechanism within the domino domain (Figs. 10C and 11B). This became paramount as a length conservation mechanism, parallel to the trend of the shear zone.

Such heterogeneous deformation can be accounted for the development of these complex patterns in the shear zones. Thus, the interpretation of domino structures must be done carefully, and their kinematic and dynamic analysis must be supported by the general framework.

\section{Acknowledgments}

We are grateful to T. Cavailhes, D. Sanderson and an anonymous referee for their insightful suggestions that greatly contribute to improve the final manuscript. The careful editorial work of Toru Takeshita also help to clarify several parts of the text.

The authors also acknowledge the funding provided by the Institute of Earth Sciences (ICT), under contract with FCT (the Portuguese Science and Technology Foundation; UID/GEO/04683/2013). Noel Moreira acknowledges Fundação Gulbenkian for the financial support through the "Programa de Estímulo à Investigação 2011" and Fundação para a Ciência e a Tecnologia, through the $\mathrm{PhD}$ grant (SFRH/BD/80580/ 2011). Authors acknowledge the English revision made by Inês Pereira.

\section{References}

Axen, G.J., 1988. The geometry of planar domino-style normal faults above a dipping basal detachment. J. Struct. Geol. 10, 405-411. http://dx.doi.org/10.1016/01918141(88)90018-1.

Bahroudi, A., Koyi, H.A., Talbolt, C.J., 2003. Effect of ductile and frictional décollements on style of extension. J. Struct. Geol. 25, 1401-1423. http://dx.doi.org/10.1016/ 0191-8141(88)90018-1.

Bluman, A.G., 2003. Elementary Statistics, a Step by Step Approach, second ed. McGrawHill, N. York 637pp.

Brosch, F.-J., Kurz, W., 2008. Fault damage zones dominated by high angle fractures within layer-parallel brittle shear zones: examples from the eastern Alps. In: In: Wibberley, C.A.J., Kurz, W., Imber, J., Holdsworth, R.E., Collettini, C. (Eds.), The Internal Structure of Fault Zones: Implications for Mechanical and Fluid-flow Properties, vol. 299. Geological Society, London, pp. 75-95. http://dx.doi.org/10. 1144/SP299.5. Special Publications.

Chaminé, H.I., Gama Pereira, L.C., Fonseca, P.E., Noronha, F., Lemos de Sousa, M.J., 2003. Tectonoestratigrafia da faixa de cisalhamento de Porto-Albergaria-aVelha-Coimbra-Tomar, entre as Zonas Centro-Ibérica e de Ossa-Morena (Maciço Ibérico, W de Portugal). Cad. Lab. Xeol. Laxe, A Coruña 28, 37-78.

Cowan, D.S., Botros, M., Johnson, H.P., 1986. Bookshelf tectonics: rotated crustal blocks within the Sovanco fracture zone. Geophys. Res. Lett. 13, 995-998. http://dx.doi. org/10.1029/GL013i010p00995.

Dabrowski, M., Grasemann, B., 2014. Domino boudinage under layer-parallel simple shear. J. Struct. Geol. 68, 58-65. http://dx.doi.org/10.1016/j.jsg.2014.09.006.

De Paor, D., 1988. Strain determination from three known stretches. J. Struct. Geol. 10, 639-642. http://dx.doi.org/10.1016/0191-8141(88)90029-6.

Dias, R., Ribeiro, A., 1993. Porto-Tomar shear zone, a major structure since the beginning of the Variscan orogeny. Comunicações do Instituto Geológico e Mineiro 79, 29-38.

Dias, R., Ribeiro, A., 1994. Constriction in a transpressive regime: an example in the Ibero-Armoricain Arc. J. Struct. Geol. 11, 1543-1554. http://dx.doi.org/10.1016/ 0191-8141(94)90032-9.

Dias, R., Ribeiro, A., Coke, C., Moreira, N., Romão, J., 2014. Arco Ibero-Armoricano; indentação versus auto-subducção. Comunicações geológicas 101 (I), 261-264.
Dias, R., Ribeiro, A., Romão, J., Coke, C., Moreira, N., 2016. A review of the arcuate structures in the Iberian variscides; constraints and genetical models. Tectonophysics 681, 170-194. http://dx.doi.org/10.1016/j.tecto.2016.04.011.

Dias, R., Moreira, N., Ribeiro, A., Basile, C., 2017. Late variscan deformation in the Iberian Peninsula; a late feature in the Laurasia-Gondwana dextral collision. Int. J. Earth Sci. http://dx.doi.org/10.1007/s00531-016-1409-x.

Dyer, R., 1988. Using joint interactions to estimate paleostress ratios. J. Struct. Geol. 10, 685-699. http://dx.doi.org/10.1016/0191-8141(88)90076-4.

Engelder, J.T., 1974. Cataclasis and the generation of fault gouge. Geol. Soc. Am. Bull. 85 (10), 1515-1522. http://dx.doi.org/10.1130/0016-7606(1974) $85<1515$ :CATGOF > 2.0.CO;2.

Figueiredo, R.P., Vargas, E.A., Moraes, A., 2004. Analysis of bookshelf mechanisms using the mechanics of Cosserat generalized continua. J. Struct. Geol. 26, 1931-1943. http://dx.doi.org/10.1016/j.jsg.2004.03.002.

Fossen, H., 2010. Structural Geology, first ed. Cambridge University Press 463 pp.

Fossen, H., Hesthammer, J., 1998. Structural geology of the Gullfaks field, northern North Sea. In: In: Coward, M.P., Johnson, H., Daltaban, T.S. (Eds.), Structural Geology in Reservoir Characterization, vol. 127. Geological Society London Special Publication, pp. 231-261. http://dx.doi.org/10.1144/GSL.SP.1998.127.01.16.

Goscombe, B., Passchier, C.W., 2003. Asymmetric boudins as shear sense indicators - an assessment from field data. J. Struct. Geol. 25 (4), 575-589. http://dx.doi.org/10. 1016/S0191-8141(02)00045-7.

Goscombe, B.D., Passchier, C.W., Hand, M., 2004. Boudinage classification: end-member boudin types and modified boudin structures. J. Struct. Geol. 26 (4), 739-763. http:// dx.doi.org/10.1016/j.jsg.2003.08.015.

Iglésias, M., Ribeiro, A., 1981. Zones de cisaillement ductile dans l'arc ibéro-armoricain. Comunicações do Instituto Geológico e Mineiro 67, 85-87.

Ismat, Z., 2006. Cataclastic flow: a means for ensuring ductility within the elastico-frictional regime. Geol. Soc. Am. Ann. Meet. Abstr. Programs 38 (7), 310.

Jaeger, J.C., Cook, N.G.W., 1979. Fundamentals of Rock Mechanics, third ed. Chapman and Hall, London 593 pp.

Karlstrom, K.E., Heizler, M., Quigley, M.C., 2010. Structure and 40Ar/39Ar K-feldspar thermal history of the Gold Butte block: reevaluation of the tilted crustal section model. In: In: Umhoefer, P.J., Beard, L.S., Lamb, M.A. (Eds.), Miocene Tectonics of the Lake Mead Region, Central Basin and Range, vol. 463. Geological Society of America Special Paper, pp. 331-352. http://dx.doi.org/10.1130/2010.2463(15). 15

Karmakar, S., Mandal, N., 1989. Rotation and offset of shear fracture boudins. Indian J. Geol. 61, 41-49.

Katz, Y., Weinberger, R., Aydin, A., 2004. Geometry and kinematic evolution of riedel shear structures, capitol reef National Park, Utah. J. Struct. Geol. 26 (3), 491-501. http://dx.doi.org/10.1016/j.jsg.2003.08.003.

La Femina, P.C., Dixon, T.H., Strauch, W., 2002. Bookshelf faulting in Nicaragua. Geology 30, 751-754. http://dx.doi.org/10.1130/0091-7613(2002)030<0751:BFIN > 2.0. $\mathrm{CO} ; 2$.

Lefort, J.P., Ribeiro, A., 1980. La faille de Porto-Badajoz-Cordobe a-t-elle contrôlé l'évolution de lócéan paleéozoique sud-Armoricain? Bull. Soc. Géol. France 455-462 7, XXII (3).

Logan, J.M., Dengo, C.A., Higgs, N.G., Wang, Z.Z., 1992. Fabrics of experimental fault zones: their development and relationship to mechanical behaviour. In: In: Evans, B., Wong, T.F. (Eds.), Fault Mechanics and Transport Properties of Rocks, vol. 51. International Geophysics, pp. 33-67. http://dx.doi.org/10.1016/S0074-6142(08) 62814-4.

Mandal, N., Khan, D., 1991. Rotation, offset and separation of oblique-fracture (rhombic) boudins: theory and experiments under layer-normal compression. J. Struct. Geol. 13, 349-356. http://dx.doi.org/10.1016/0191-8141(91)90134-5.

Mandal, N., Chakraborty, C., Samanta, S.K., 2000. Boudinage in multilayered rocks under layer-normal compression: a theoretical analysis. J. Struct. Geol. 22 (3), 373-382. http://dx.doi.org/10.1016/S0191-8141(99)00156-X.

Mandal, N., Dhar, R., Misra, S., Chakraborty, C., 2007. Use of boudinaged rigid objects as a strain gauge: insights from analogue and numerical models. J. Struct. Geol. 29 (5), 759-773. http://dx.doi.org/10.1016/j.jsg.2007.02.007.

Mandl, G., 1987. Tectonic deformation by rotating parallel faults: the "bookshelf' mechanism. Tectonophysics 141 (4), 277-316. http://dx.doi.org/10.1016/00401951(87)90205-8.

Mandl, G., 2000. Faulting in Brittle Rocks: an Introduction to the Mechanics of Tectonic Faults. Springer-Verlag, Berlin978-3-662-04262-5.

Misra, S., Mandal, N., Chakraborty, C., 2009. Formation of Riedel shear fractures in granular materials: findings from analogue shear experiments and theoretical analyses. Tectonophysics 471, 253-259. http://dx.doi.org/10.1016/j.tecto.2009.02.017.

Moreira, N., 2012. Caracterização estrutural da zona de cisalhamento Tomar-BadajozCórdova no sector de Abrantes. Unpublished MSc thesis. University of Évora 225 pp.

Moreira, N., Pedro, J., Dias, R., Ribeiro, A., Romão, J., 2011. Tomar-Badajoz-Córdoba shear zone in Abrantes sector; the presence of a kilometric sheath fold? In: Deformation Mechanisms, Rheology and Tectonics, DRT 2011 Meeting, Oviedo, Espanha, pp. 90.

Moreira, N., Araújo, A., Pedro, J.C., Dias, R., 2014. Evolução geodinâmica da Zona de Ossa-Morena no contexto do SW Ibérico durante o Ciclo Varisco. Comunicações geológicas 101 (I), 275-278.

Moreira, N., Romão, J., Pedro, J., Dias, R., Ribeiro, A., 2016. The Porto-Tomar-Ferreira do Alentejo shear zone tectonostratigraphy in Tomar-Abrantes sector (Portugal). GeoTemas 16 (1), 85-88 1576-5172.

Nance, R.D., Gutiérrez-Alonso, G., Keppie, J.D., Linnemann, U., Murphy, J.B., Quesada, C., Strachan, R.A., Woodcock, N.H., 2012. A brief history of the Rheic Ocean. Geosci. Front. 3 (2), 125-135. http://dx.doi.org/10.1016/j.gsf.2011.11.008.

Nixon, C.W., Sanderson, D.J., Bull, J.M., 2011. Deformation within a strike-slip fault network at Westward Ho!, Devon U.K.: domino vs conjugate faulting. J. Struct. Geol. 
33, 833-843. http://dx.doi.org/10.1016/j.jsg.2011.03.009.

Passchier, C.W., Myers, J.S., Kröner, A., 1990. Field Geology of High-grade Gneiss Terrains. Springer-verlag Berlin Heidelberg, New York3-540-53053-3 150 pp.

Passchier, C.W., Trouw, R.A.J., 2005. Microtectonics, second ed. Springer, New York9783-540-64003-5 $382 \mathrm{pp}$.

Pereira, M.F., Silva, J.B., Drost, K., Chichorro, M., Apraiz, A., 2010. Relative timing of the transcurrent displacements in northern Gondwana: U-Pb laser ablation ICP-MS zircon and monazite geochronology of gneisses and sheared granites from the western Iberian Massif (Portugal). Gondwana Res. 17, 461-481. http://dx.doi.org/10.1016/j. gr.2009.08.00.

Ribeiro, A., 2002. Soft Plate and Impact Tectonics. Springer Verlag, Berlin 978-3540679639, 324 pp.

Ribeiro, A., Munhá, J., Dias, R., Mateus, A., Pereira, E., Ribeiro, M.L., Fonseca, P., Araújo, A., Oliveira, T., Romão, J., Chaminé, H., Coke, C., Pedro, J., 2007. Geodynamic evolution of SW Europe variscides. Tectonics 26 (6). http://dx.doi.org/10.1029/ 2006TC002058.

Ribeiro, A., Munhá, J., Mateus, A., Fonseca, P., Pereira, E., Noronha, F., Romão, J., Rodrigues, J.F., Castro, P., Meireles, C., Ferreira, N., 2009. Mechanics of thickskinned variscan overprinting of cadomian basement (Iberian Variscides). Compt. Rendus Geosci. 341 (2-3), 127-139. http://dx.doi.org/10.1016/j.crte.2008.12.003.

Romão, J., Metodiev, D., Dias, R., Ribeiro, A., 2013. Evolução geodinâmica dos sectores meridionais da Zona Centro-Ibérica. In: In: Dias, R., Araújo, A., Terrinha, P., Kullberg, J.C. (Eds.), Geologia de Portugal, vol. 1 Escolar Editora, 206-257. ISBN: 978-972-
592-364-1.

Romão, J., Moreira, N., Dias, R., Pedro, J., Mateus, A., Ribeiro, A., 2014.

Tectonoestratigrafia do Terreno Ibérico no sector Tomar-Sardoal-Ferreira do Zêzere e relações com o Terreno Finisterra. Comunicações geológicas 101 (I), 559-562.

Samanta, S.K., Mandal, N., Chakraborty, C., 2002. Development of different types of pullapart microstructures in mylonites: an experimental investigation. J. Struct. Geol. 24 (8), 1345-1355. http://dx.doi.org/10.1016/S0191-8141(01)00139-0.

Scott, D.W., 2009. Sturges' rule. WIRs Comput. Stat. 1 (3), 303-306. http://dx.doi.org/10 1002/wics.035.

Shelley, D., Bossière, G., 2000. A new model for the Hercynian orogen of Gondwanan France and Iberia. J. Struct. Geol. 22, 757-776. http://dx.doi.org/10.1016/S01918141(00)00007-9.

Sibson, R.H., 1977. Fault rocks and fault mechanism. J. Geol. Soc. Lond. 133 (3), 191-213. http://dx.doi.org/10.1144/gsjgs.133.3.0191.

Stewart, S.A., Argent, J.D., 2000. Relationship between polarity of extensional fault arrays and presence of detachments. J. Struct. Geol. 22, 693-711. http://dx.doi.org/10. 1016/S0191-8141(00)00004-3.

Walsh, J.J., Watterson, J., 1991. Geometric and kinematic coherence and scale effects in normal fault systems. Geol. Soc. Lond. Spec. Publ. 56, 193-203. http://dx.doi.org/10. 1144/GSL.SP.1991.056.01.13.

Wernicke, B., Burchfiel, B.C., 1982. Modes of extensional tectonics. J. Struct. Geol. 4 (2), 105-115. http://dx.doi.org/10.1016/0191-8141(82)90021-9. 